\title{
Small saving in India with special reference to Saving pattern of weavers in Handloom sector of Bodoland Territorial Area Districts(BTAD), Assam, India
}

\author{
Dr. Konita Basumatary \\ Assist. Prof, Department of Economics, Bodoland University, Kokrajhar, BTAD, Assam.
}

\begin{abstract}
Small saving scheme is one of the key investment avenues for individual investor. It encourages small-income investors to invest and earn high returns and to save on income tax as well. In this paper the growth of small saving from 2001-02 to2017-18 has been analyzed by adopting non linear growth model. The paper also examined factors leading to saving differential of weavers in the handloom sectors of BTAD areas. The study is based on both primary and secondary data. To determine the relationship between various variables multiple regressions has been used. It is found that saving of weaver is positively determined by their monthly wages and negatively by family size and they are found significant at 1 percent level. Again the saving of weavers is found to be negatively determined by dependent children. Saving differences among gender and community is found insignificant, that mean we cannot say whether saving is greater (smaller) for male than female and for STs than non ST. So we cannot find a differences in saving behaviour among gender and community although there's found a significant difference in saving among marital status and types of weaver.
\end{abstract}

Keywords:

Small saving, Weaving, Wage, and Weavers

Article Received: 18 October 2020, Revised: 3 November 2020, Accepted: 24 December 2020

\section{Introduction}

The small saving schemes in India are framed by the Central Government under the Government Savings Bank Act, 1873 and Government Savings Certificates Act 1959 and the Public Provident Fund Act 1968. Small Saving Scheme includes Total Deposits, Saving Certificate and Provident funds. Total deposits comprises of Post Office Bank Deposits, MGNREG, National Saving Scheme, 1987, National Saving Scheme, 1992, Monthly Income Scheme, Senior Citizen Scheme, Post Office Time Deposits (1year to5 year time deposit), Post Office Recurring Deposits, Post Office Cumulative Time Deposits and others. Saving Certificates includes National Savings Certificate VIII issue, Indira Vikas Patras, Kisan Vikas Patras, Kisan Vikas Patras - 2014, National Saving Certificate VI issue, National Saving Certificate VII issue, and Other Certificates. The maturity period of the small saving schemes, currently in operation, varies from a very short period (saving deposits) to over fifteen years (Public provident Fund). Interest rates on the small saving scheme are fixed by the Central Government from time to time.

Literature shows that Resource mobilization from small savings in India witnessing a steady growth since 1980s with the growing need to finance a large part of the fiscal deficit in the face of limited possibility in accessing funds from the market. Past trends indicate significant growth in small savings collection from Rs.792 crore in 1970-71 to Rs.18,920 crore in 1990-91 and Rs. 75,542 crore in 1999-2000 (RBI Bulletin Occasional Series). As per the annual report on analysis of trend of small saving collection 201718 provided by ministry of finance, government of India, overall, there has been a rise in terms of 
both gross and net Small savings collections during the year 2017 - 18 as compared to the collections secured in 2016 - 17. During that year a substantial increase of 19.18 percent in gross collections and an impressive increase of 43.66 per cent in terms of net collections have been recorded in the country. The share of Post Office Savings Account in total collections during the period under report remains the highest in overall gross collections at 42.98 per cent followed by Public Provident Fund (PPF) at 15.58 per cent, National Savings Time Deposits at 10.27 per cent primarily dominated by 1 - Year Time Deposits, and National Savings Recurring Deposits at 8.34 per cent. Other schemes with remarkable contribution to overall gross collections are National Saving Monthly Income Account at 6.77 per cent and Senior Citizens' Savings Scheme Account at 6.48 per cent

\section{Theoretical framework of saving}

The life cycle hypothesis given by Modigliani and Brumberg 1954, view household consumption and saving behaviour over long periods with intention of allocating their consumption in best possible way over their entire life time. The life cycle theory does not rely only on single value (income) for marginal propensity to consume but implies different marginal propensities to consume out of permanent income, transitory income and wealth (Rudiger, D et.al 2004). Life cycle hypothesis helps us to link the consumption and saving behaviour by considering the demographic variable. According to this theory, at the beginning (early age) of life, average income is relatively low and individual borrow to keep certain level of consumption. However in the middle years of life, the individual has high amount of income both from assets and labour. In the middle age the individual is considered to save for future and in later years (old age/ retirement) whatever is save is spent, so individual dissaves in old age.

The inter-temporal choice theory also explains the factors that affect consumer decision of saving and consumption. According to the model of inter-temporal choice various macroeconomic variable like interest rate, expected income in present and future and also the wealth affect the saving and consuming behaviour of the consumers.

According to Keynes Liquidity Preference Theory, there are three motive of holding money. They are Transaction, Precautionary and Speculative. The Behavioral Economists has given eight motives of saving which includes precautionary, improvement, independence, lifecycle, inter-temporal substitution motive, enterprising, bequest, avarice and down payment. They have also considered two aspects of saving that are time preference (preference of present over future, rate of interest reflect time preference) and self control (choice to take pain in order to gain something). Saving of a household is determined by numbers of factors including uncertainty, wealth, risk horizon, unemployment, self employment, interest rate and also by the demographic variables.

Different Researchers had pointed out different factors leading to the motive behind saving. Katona (1975) had identified six motives for saving which includes (a) for emergencies, (b) for old age, (c) for children needs (d) To buy house (e) for holidays and (f) to have fund in reserve for necessities. Gatt, W (2014) while studying the saving behavior of household in Malta during the period 2000-2012, found that household tended to adjust their saving to keep a buffer of financial resources as insurance against future income shocks. His study also pointed out that 1 per cent increased in real deposit rate is associated with increased in saving rate by 0.8 to 1.1 per cent. Yao, R et.al (2014) had examined the saving behavior of Chinese urban consumers. Their finding indicates emergency, children education and retirement as an important motive behind saving of Chinese consumers. They have also pointed out certain seasons and situation of life necessitate for certain saving needs and 
pattern. Savings are also shaped by social environment, societal norms, expectation related by life cycle. Cho, S.H (2009) found demographic factors as an important variable explaining attitude towards the saving behavior. $\mathrm{He}$ also considered saving goal and individual regulatory orientation toward saving attitude. The saving goals can be promotional goals (children education, buying durable goods, travels etc) and preventive goals (retirement, emergencies, securities, paying taxes etc.) and it increased the likelihood of saving as pointed out in his study.

\section{Significance of the study}

Small saving scheme are important source of household saving in India. It constitutes a major segment of the financial sector, particularly, in terms of mobilization of savings. Different small saving had mobilized money from household and channelized it to the government in order to finance central and state expenditure. Small saving scheme had also helped to support the social security of different sections.

Handloom is unorganized sector and considered to be one of the important sectors in generation of employment to the BTAD area. Weavers are the main part in handloom industry and they are considering being a low income earner. Here the saving behaviour of weavers (who are considered to earn low wage (income) in two districts of BTAD, Assam, India is analyzed. A weaver saving is important since it can increase investment and enhance their family living standard. It can also help them to meet their household expenses, children education and emergency. Actually savings of an individual or household depends on the ability to save and the desire or motivation for saving which can be considers two proximate determinants. The ability to save depends on the level of income, other things being the same which is again governed by consumption expenditures, which in turn, is influenced by the size of the family, age composition, availability of desired goods and services, and their standard of living etc. From the field study, it is found that, 30 per cent of weavers reports to have expanses above their monthly wage. Mainly the weavers who have dependent children, no house of their own are more likely to have expanses exceeding income. The precautionary motive and children's education are commonly reported motive of saving among weavers in the study area. The behaviour of the saving pattern of weavers is very vital and it will help in understanding the policy formulation and on development and regulation of the savings market in order to ensure the promotion and protection of interests of small and household investors. The main goals of this paper is to examine the growth of small saving in India and also to examine the mode or pattern of saving of weavers and factors determining saving of weavers in handloom sector.

Since saving is a function of income, in this study wage of the weaver is taken as their income. Saving of weaver is calculated as excess of income (wage) over consumption expenditure. We could not take into account the medium and long term saving (future income) in different institution since the interrogation with weavers shows that a very low proportion of weaver have access to financial institution and they do not have any such investment. Unfortunately we could not take into account the debt, wealth and assets posses by weavers which have impact on saving.

\section{Methodology and data collection}

To analyze the growth of small saving in India, data has been collected from RBI Bulletin different series and Accountant General, Post and Telegraphs for the year 1990-91 to 2017-18. However Non-Linear Growth Model has been used to estimate growth trend from the year 200102 to 2017-18. Non-linear growth model has been adopted because data that we are considering exhibits non-linear characters. Non linear growth model is expressed as

$$
Y_{i}=A_{i} e^{b i t} e^{u i}
$$

Where $\mathrm{Yi}$ is regressand (Dependant variable in a regression), A's are constant, b's are coefficient of time variable $t$ (regressor/independent variable) or 
the rate of growth and u's is error term. After log transformation the non linear model becomes a linear model as given below

\section{$\log Y_{i}=\log A_{i}+b_{i} t+u_{i}$}

Again to analyze the saving pattern of weaver in Handloom sector of BTAD, data has been collected from Kokrajhar and Chirang districts, the two districts of BTAD, Assam. From two districts six (6) blocks has been selected, three (3) blocks from each district. From 3 blocks in each districts ten (10) villages are selected and from those villages, 10 weaving centre has been selected. Total sample size in two districts (Kokrajhar and Chirang) is 200 numbers that is 132 female and 68 male. Again out of 200 sample132 numbers of weavers were STs and 68 numbers were Non ST. Blocks and villages are selected purposively taking into account the weaving activities. Respondents in selected weavings were identified through simple random sampling. For testing hypothesis data are regressed using SPSS 16 version.

To determine the relationship between various variables multiple regressions has been taken. Multiple regressions to determine saving of weavers in relation to wage, family size and dependent children is stated as

$$
Y=a+b X_{1}+c X_{2}+d X_{3}+U
$$

Where $\mathrm{Y}$ is saving of weaver explained by constant (a), $X_{1}, X_{2}$ and $X_{3}$ are wage and family size or total family member and dependent children (children below 20 year of age in household/ family) respectively and error term (U).

Again the regression model depicting saving among various social groups is given as

$$
Y=a+b 1 M+b 2 T P+b 3 G+b 4 C+U
$$

Here all the explanatory variables are dummy Variable.

$\mathrm{Y}$ is saving, $\mathrm{M}$ is marital status where $\mathrm{M}=0$ for married and 1 for unmarried. TP types of weaver where $\mathrm{TP}=0$ for part time weaver and $\mathrm{TP}=1$ for full time. $G$ is gender where $G=0$ for male and 1 for female, $\mathrm{C}$ is community where $\mathrm{C}=0$ for STs and 1 otherwise. $\mathrm{a}$ is constant, b1,b2,b3,b4 are slope of explanatory variables. $\mathrm{U}$ is error term.

To determine the coefficient of saving among various different income/wage (monthly) groups, the regression equation is stated as

$\mathrm{S}=\beta \mathrm{O}+\beta 1 \mathrm{I}(3000)+\beta 2 \mathrm{I}(3001$ to 6000$)+\beta 3 \mathrm{I}$ (6000 above)

Where $\mathrm{S}$ is saving and I is income/wage.

To determine saving among different age group, the regression equation is given as

$$
\begin{gathered}
\mathrm{S}=\beta \mathrm{o}+\beta 1 \mathrm{~A}(15 \text { to } 25)+\beta 2 \mathrm{~A}(26 \text { to } 35)+\beta 3 \mathrm{~A} \\
\text { (36 to } 45)+\beta 4 \mathrm{~A}(45 \text { above })+\mathrm{U} .
\end{gathered}
$$

Where $\mathrm{S}$ is saving, $\mathrm{A}$ is Age and $\mathrm{U}$ is Error term.

\subsection{Test of multicollinearity}

Multicollinearity is a situation that occurs when independent variables in a regression model are correlated. To identify the problem of multicollinearity in the model, Tolerance and Variance Inflation Factor (VIF) value are accessed. VIF of above 5 or 10 and tolerance and of less than 0.20 or 0.10 are often regarded as indicating multicollinearity.

\subsection{Test of stationary}

Before any time series result is analyzed, it is necessary to determined whether the time series data that we undertake is stationary or not. It is only when the data are stationary or contain no unit root; we can estimate the data series. If it contain unit root, then we have to make it stationary by differencing the data sets. In this study, the test for stationary was performed individually for all the variables (small saving variables) by performing Augmented Dickey Fuller (ADF) test. If the time series variables were not stationary, the series was differenced and Augmented Dickey Fuller (ADF) test was applied again on the differenced time series to make it 
stationary. In this paper post office saving (receipt), monthly income scheme (outstanding), public provident fund (receipt), national saving scheme 1992 (receipt), senior citizen scheme (outstanding), national saving scheme 1987 (receipt) were found stationary at level $\mathrm{I}(0)$. National saving $\quad$ scheme 1987 (outstanding),Saving certificate (outstanding), post office recurring deposit (outstanding), national saving scheme1992 (outstanding), Public

Table 1Descriptive statistics showing growth of small saving in India

\begin{tabular}{|l|l|l|l|l|l|}
\hline Variables & Coefficient & T value & Sig & R square & $\begin{array}{l}\text { Adj.R } \\
\text { Square }\end{array}$ \\
\hline Post office saving (R) & .0514216 & 3.95 & $0.001 * *$ & 0.5093 & 0.4766 \\
\hline Post office saving (O) & .0036029 & 2.04 & $0.050^{*}$ & 0.2300 & 0.1749 \\
\hline National saving scheme1987(R) & -.06625 & -7.57 & $0.000 * * *$ & 0.7924 & 0.7785 \\
\hline National saving scheme1987(O) & -.0033235 & -1.95 & 0.071 & 0.2137 & 0.1575 \\
\hline National saving scheme1992(R) & -.0658578 & -4.04 & $0.001 * *$ & 0.5205 & 0.4885 \\
\hline National saving scheme1992(O) & -.5376225 & -16.28 & $0.000^{* * *}$ & 0.9464 & 0.9428 \\
\hline Monthly income scheme(R) & -.0264643 & -1.21 & 0.248 & 0.1012 & 0.0321 \\
\hline Monthly income scheme(O) & .0217868 & 3.66 & $0.002 * *$ & 0.4714 & 0.4362 \\
\hline Senior citizen scheme(R) & .0250549 & 0.86 & 0.409 & 0.0629 & -0.0223 \\
\hline Senior citizen scheme(O) & .0309011 & 2.92 & $0.013 * *$ & 0.4146 & 0.3658 \\
\hline Post Office Time Deposits(R) & .0165357 & 2.45 & $0.029 * *$ & 0.3152 & 0.2625 \\
\hline Post Office Time Deposits(O) & .0037143 & 0.79 & 0.444 & 0.0457 & -0.0277 \\
\hline Post Office Recurring Deposits(R) & .0233571 & 1.80 & 0.095 & 0.1994 & 0.1378 \\
\hline Post Office Recurring Deposits(O) & -.0229853 & -2.10 & $0.054 *$ & 0.2393 & 0.1849 \\
\hline Saving Certificates(R) & -.0158286 & -1.16 & 0.267 & 0.0938 & -0.0241 \\
\hline Saving Certificates(O) & -.0009853 & -0.12 & 0.908 & 0.0010 & -0.0704 \\
\hline Public Provident Fund(R) & .0464706 & 9.53 & $0.000 * * *$ & 0.8583 & 0.8488 \\
\hline Public Provident Fund(O) & -.0020735 & -2.44 & $0.028 * *$ & 0.2987 & 0.2486 \\
\hline Source: Stata ouput, R stans for & & & \\
\hline
\end{tabular}

Source: Stata output, $\mathrm{R}$ stands for receipt and $\mathrm{O}$ for outstanding,* indicates significant at 10 per cent, ** indicates significant at 5 percent and $* * *$ indicates significant at 1 percent.

Small saving in India including post office saving (receipt and outstanding), monthly income scheme (outstanding), senior citizen scheme (receipt and outstanding), public provident fund (receipt) has a positive trend. It is clear from the descriptive statistics that post office saving (receipt) has increased by 5 per cent per year during the period 2001-02 to 2017-18. However post office saving outstanding has increased by provident fund (outstanding) are found stationary at level I(1) or after first differenced. Post office saving (outstanding), monthly saving scheme (receipt), saving certificate (receipt),post office time deposit (receipt), post office time deposit (outstanding) are found stationary at level I(2) or after second differenced. (Detail of Augmented Dickey Fuller test for stationary is given in appendices).

5. Discussion and results 
slope of post office time deposit (outstanding) is positive, it is not sure of the rate of changes because it is found to be insignificant.

Small saving including national saving scheme 1987 (receipt and outstanding), National saving scheme 1992 (receipt and outstanding), saving certificate (receipt and outstanding), post office recurring deposit (outstanding) has a negative trend. National saving scheme 1987 (receipt) has found to decreased by 6 per cent, national saving scheme 1992 (receipt and outstanding) by 6.5 per cent and 5.3 per cent respectively, post office recurring deposit (outstanding) is also found to decline by 2 percent per year during 2001-02 to 2017-18.

Table 2 Respondents' wages from weaving in Kokrajhar and Chirang districts

\begin{tabular}{|c|c|c|}
\hline Monthly Wages & Total & Percentage \\
\hline Rs. $1500-3000$ & 95 & 47.5 \\
\hline Rs. $3001-4500$ & 58 & 29 \\
\hline Rs. 4501-6000 & 32 & 16 \\
\hline Rs. Above 6000 & 15 & 7.5 \\
\hline
\end{tabular}

Source: field study

From table 2, it is observed that 47.5 percent ( 95 observations out of 200) weavers earned wages between 1500-3000, 29 per cent earned between '3001 to 4500', 16 per cent earned between ' 4501 to 6000 ' and only 7.5 per cent earned above 6000 in a month. From the table, it is observed that 47.5 per cent of weavers hardly earned Rs.50 to 100 a day, 29 per cent earned between Rs 100 to Rs. 150,16 per cent earned between Rs. 150 to 200 a day. Wages of the weavers depends upon their production of cloth. One of the causes for low production is that they take their own time to work; they may begin and leaves their work on their pleasure. They are independent to their decision. Production and productivity of weavers also depend upon the modernization of loom. In our study area, it is observed that most of the looms are simple and only the small proportion of looms is attached of Jacquard. Another reason observed during field study is that, weaving is a tiring job. Weavers complained that if they try to weave more to make more money, they can't wake up the next morning due to severe body pain. Still they prefer to weave due to lack of employment opportunities and weaving gives them satisfaction due to flexible shift. When we go through the secondary data of weavers' engagement in Handloom sector in BTAD, we found a tremendous decline of weaver engagement in handloom sector. Handloom weavers are no longer willing to stay with handloom and they shifted to other job as soon as they get opportunities. The reason for this may be the technological changes (powerloom) and low wages. Due to lack of weavers and financial facilities, handlooms have been declining in BTAD area. Attention should be given for the low wages of weaver and more avenues should be given to them to enhance their living conditions.

Table 2 a Comparing mean wages among different groups of weaver

\begin{tabular}{|c|c|c|}
\hline \multicolumn{2}{|c|}{} & Mean wages in Month (Rs.) \\
\hline \multirow{2}{*}{ Weaving district } & Kokrajhar & 3425 \\
\cline { 2 - 3 } & Chirang & 4039 \\
\hline \multirow{2}{*}{ Gender } & Male & 4900 \\
\cline { 2 - 3 } & Female & 3200 \\
\hline Community & STs & 3120 \\
\cline { 2 - 3 } & Non STs & 4860 \\
\hline Marital status & Married & 3900 \\
\hline
\end{tabular}




\begin{tabular}{|l|l|l|}
\hline & Unmarried & 3610 \\
\hline
\end{tabular}

Source: field study

From table 2a, wages differences among gender, community and between Kokrajhar and Chirang district can be observed. To examine which social groups earn more wages, their monthly mean wages is calculated. It is found that monthly mean wage in Chirang district is higher than Kokrajhar district, male earn higher than female and Non STs earn higher than STs. The major contribution leading to wage differences between male and female is that, 30 numbers of female weavers are working as part time and none of male weavers is found to be part time weaver. On average female weavers are found to spend less time in weaving then male counterpart due to household duties and caring responsibilities. The average wage of weavers in chirang district is Rs. 4039 per month compared to Rs. 3425 per month in Kokrajhar district. Non STs Average wage is Rs. 4860 per month and that of ST is Rs. 3120.
When we take into account the average wage gender wise, we have found that it is Rs. 4900 in a month for male and for female it is Rs.3200 on average in a month. The gap between married and unmarried is small and is found to be insignificant. Another factor leading to wage differential among weaving districts, community and gender is due to the differences in production (in numbers) and due to differences in productivity. It is found that the mean productivity of Male is 0.529 metres per hours and for female it is 0.442 metres per hours, for Kokrajhar district it is 0.460 metres per hour and for Chirang it is 0.482 metres per hour, for STs it is 0.442 , for Non STs it is 0.529 metres per hours. When we examine the production differences, it is found that for Male it is 30 numbers in a month and for female it is only 16 numbers, for non STs it is 29 numbers and for ST it is 16 numbers in a month.

Table 3 Mode of saving of Weavers in Handloom sector

\begin{tabular}{|l|l|l|}
\hline Form of saving & Number of weaver & Percentage \\
\hline Liquid Assets (Cash in Hand) & 40 & 20 \\
\hline Bank/post office/insurance & 28 & 14 \\
\hline Animals like goats, pigs, buffalos, ox, etc & 96 & 48 \\
\hline In form of assets like cycle, scooter, radio, chair, etc & 36 & 18 \\
\hline Total & 200 & 100 \\
\hline
\end{tabular}

Source: Author's calculation based on field study

From field study it is found that 20 per cent of weaver prefer keep cash in hand,14 per cent prefer in bank and post office, 48 per cent prefer to save in-kind and 18 in form of assets. According to the report of respondents savings in cash are usually for short terms and are small in amount. Cash is saved in a variety of places - in small boxes, earthen pots, the kitchen shelf, etc. It is mostly the women who take initiative for this type of savings.
The amounts range from Rs.50 to Rs.500. This money is used to entertain guests, meet demands of the children, take care of illness, manage small household events, and the like. Savings in-kind is probably the most diversified in use and form among the weavers. In-kind saving may take the form of land, jewelry, livestock etc. Saving inkind is options to many weavers because those commodities are easy to both buy and sell.

\section{Table 4 Types of Account weavers' preference to save}

\begin{tabular}{|l|l|l|}
\hline Savers Preference of Accounts in Financial Institutions & No. of Households & Percentage \\
\hline Current account & 0 & 0 \\
\hline Savings account & 10 & 5 \\
\hline
\end{tabular}




\begin{tabular}{|l|l|l|}
\hline Fixed deposit (Bank + post office) & 08 & 4 \\
\hline Recurring deposit (Bank + post office) & 10 & 5 \\
\hline others & 172 & 86 \\
\hline Total & 200 & 100 \\
\hline
\end{tabular}

Source: Author's calculation based on field study

Table 4 shows the types of account weavers' prefer to save. From above table it is observed that 172 respondents prefer others options. According to them, opening an account can be a lengthy and cumbersome process where lot of documentation involved, usually a long waiting time. They also fear that the work may take up a full day of the potential customer, which may lead to loss of at least a day's income. We have also observed that 72 percent of weavers are without having bank account.

Table 5 Descriptive statistics showing the relation between saving and wage of weaver

\begin{tabular}{|c|c|c|c|c|c|c|}
\hline & \multirow[t]{2}{*}{ Coefficient } & \multirow[t]{2}{*}{ Standard error } & \multirow[t]{2}{*}{$\mathrm{T}$ value } & \multirow[t]{2}{*}{$\mathrm{P}$ value } & \multicolumn{2}{|c|}{ Collinearity statistics } \\
\hline & & & & & Tolerance & VIF \\
\hline Constant & 485.330 & 189.619 & 2.560 & .011 & & \\
\hline Wages & .321 & .021 & 15.65 & $.000 * * *$ & .985 & 1.015 \\
\hline Family size & -227.968 & 51.039 & -5.446 & $.000 * * *$ & .437 & 2.289 \\
\hline $\begin{array}{l}\text { Dependent } \\
\text { children }\end{array}$ & -165.237 & 121.615 & -1.359 & .176 & .438 & $\begin{array}{l}2.282 \\
\mathrm{R}^{2}=.61\end{array}$ \\
\hline
\end{tabular}

Dependant variable is saving, $* * *$ significant at 1 percent.

From above table, it is clearly visible that our model is free from multicollinearity problem. According to the estimated regression, it is found that the saving of weaver is positively determined by their monthly wages and negatively by family size and they are found significant at 1 percent level. Again the saving of weavers is found to be negatively determined by dependent children even though the statistical result is insignificant. So, according to the results, larger family size and having dependent children (children below age 20 ) in household is associated with less saving.

Table 6 Descriptive statistics showing saving among various groups

\begin{tabular}{|l|l|l|l|l|l|l|}
\hline $\begin{array}{l}\text { Explanatory } \\
\text { variable }\end{array}$ & Coefficient & Standard error & t- value & p-value & \multicolumn{2}{l}{$\begin{array}{l}\text { Collinearity statistics } \\
\text { Tolerance }\end{array}$} \\
\hline Constant & 426.328 & 269.298 & 1.58 & .115 & & \\
\hline Marital Status & 463.93 & 120.918 & 3.837 & $.000^{* * *}$ & .955 & 1.047 \\
\hline Type of weaver & 394.699 & 167.130 & 2.362 & $.019 * *$ & .906 & 1.103 \\
\hline Gender & -162.863 & 217.695 & -.748 & .455 & .320 & 3.126 \\
\hline Community & 391.524 & 217.801 & 1.798 & .074 & .315 & 3.172 \\
\cline { 5 - 7 } & & & & & & $\mathrm{R}^{2}=0.16$ \\
\hline
\end{tabular}

Dependant variable is saving, $* * *$ significant at 1 percent, $* *$ significant at 5 percent.

Saving differences among gender and community is found insignificant, that mean we cannot say whether saving is greater (smaller) for male than female and for STs than non ST. So we cannot 
find a differences in saving behaviour among gender and community although there's found a significant difference in saving among marital status and types of weaver. Yup and Hanna (2010) found married household to save more than single female and black household less likely to save than white household. Blanc, J.L et.al (2015) found that the households whose head is female, young or divorced were significantly more likely to have expenses exceeding income; in contrast, wealthier households are less likely to incur in expenses higher than income.

Table 7 Descriptive statistics showing saving among various income groups

\begin{tabular}{|l|l|l|l|l|}
\hline $\begin{array}{l}\text { Income } \\
\text { group(Rs.) }\end{array}$ & coefficient & Standard error & T value & P value \\
\hline Up to 3000 & .307 & .042 & 7.307 & $.000^{* * *}$ \\
\hline 3001 to 6000 & .341 & .089 & 3.828 & $.000 * * *$ \\
\hline Above 6000 & .488 & .143 & 3.410 & $.005 * *$ \\
\hline
\end{tabular}

Dependant variable is saving, $* * *$ significant at 1 percent, $* *$ significant at 5 percent.

Here the saving among various wage group of weavers are studied to explore whether the coefficient of various wage group differ significantly. It is depicted from the table that the coefficient of income increases with increased in wage (income) and they are found statistically significant.

Table 8 Coefficient of different age group and their saving

\begin{tabular}{|l|l|l|l|l|}
\hline Age group & Coefficient & Standard error & T value & P value \\
\hline $15-25$ & 11.824 & 5.900 & 2.004 & $.049 *$ \\
\hline $26-35$ & 11.588 & 26.00 & .446 & .657 \\
\hline 36 to 45 & 43.854 & 50.174 & .874 & .394 \\
\hline 45 above & 38.846 & 10.835 & 3.585 & $.009 * * *$ \\
\hline
\end{tabular}

Dependant variable is saving, $* * *$ significant at 1 percent, $* *$ significant at 5 percent.

Here the coefficient of age group 15-26' and 45 above is found significant at 5 per cent level and 1 per cent level respectively. So the younger weaver and older weavers are more likely to save than the weaver of age group between ' 26 to 45'. The coefficient of age group 26-35 and 36-45 are found insignificant. In this age group it is observed that they are more likely to have more expenses toward their household activities, educating children, buying of house and land etc. and these may be the reasons for less saving.

\section{Conclusion:}

Small saving is found to be very significant to the low income earner and to middle class people. This form of investment helps go about the daily needs and secure future at the same time. The study revealed that small saving in India including post office saving (receipt and outstanding), monthly income scheme (outstanding), senior citizen scheme (receipt and outstanding), public provident fund (receipt) has a positive slope. However some of the small saving including national saving scheme 1987(receipt and outstanding), National saving scheme 1992 (receipt and outstanding), saving certificate (receipt and outstanding), post office recurring deposit (outstanding) has a negative trend. To attract more saving in small saving scheme Government should take into account the interest rate of the same which in turn help the Government to borrow more from small savings funds. 
It is also observed that differences in wage resulted in saving differential among weavers in the study area. Higher wage is found to have positive effect on saving. However it is observed that wages, productivity as well of living standard of weavers is not satisfactory in the study area. If productivity of weavers in handloom sector of BTAD is enhanced, it will truly raise wage, saving and living condition of weavers.

It is also found that savings of weavers in BTAD, Assam is mainly practiced through informal, semi-formal, or formal mechanisms in the form of cash, in-kind, or account-based savings. Weavers save in form of asset base (land holdings, livestock, jewellery), and availability of lump sum amounts to cope with crises. From field study, it is observed that 30 per cent of respondents have excess of expenses over their monthly income/wage which results in an overdependence on credit. As the study suggest wage as most important determinant of saving. To enhance saving of weavers, the wage rate should be increased.

\section{References}

[1] Angus, D (2010), "Understanding the Mechanisms of Economic Development", Journal of Economics Perspectives Volume 24 no.3 Pp 3-16.

[2] Ando, A. and F. Modigliani (1963), "The Life Cycle Hypothesis of Saving: Aggregate Implications and Tests", The American Economic Review, Vol. 53, No. 1. (Mar., 1963), pp. 55-84

[3] Bori, Geethshree, and Neog Rupjyoti (2017), "Emerging Trends in Woven Textile Fabrics Design of Tribal Mising community in Assam" International journal of Applied and Natural Sciences (IJANS) vol.6 issue 5, Pp7-14

[4] Blanc, J.L., Porpiglia, A., Teppa, F., Zhu, J and Ziegelmeyer, M (2015), Household Saving Behavior and Credit Constraints in Euro Areas, Working paper series, No. 1790.
[5] Cho, S.H (2009), Role of Saving Goals in Saving Behavior: Regulatory Focus Approach, Ph.D Thesis submitted to the Graduate School of The Ohio State University, Columbus Ohio.

[6] Carroll, C. D (1992) “The Buffer Stock Theory of Saving: Some Macroeconomic Evidence, Brookings Papers on Economic Activity 1992(2) pp 61-156.

[7] Costas,M (2004), "A Retrospective on Friedman's Theory of Permanent Income" WPO4/01, The Institute of Fiscal Studies.

[8] Govt.of India, Ministry of Finance, Department of Economics Affairs, Annual report on analysis of trends of small saving collection 2017-18

[9] Gatt, W (2014), The Determinants of Household Saving Behaviour in Malta, Working paper 03/2014.

[10] Gupta, K.L. (1970). Personal Saving In Developing Nations, Further Evidence, Economic Record, June House, PVT Ltd. New Delhi

[11] Katona, G (1975), Psychological Economics, Elsevier Scientific Publishing Company, New York.

[12] Lobes (1987), -Analysis of investors risk Perception towards mutual funds servicesll, International Journal of Business and Management, Vol 4, pp.234 - 236

[13] Lewis, A. (1954), "Economic development with unlimited supply of labour," The Manchester School, 22(2), 139-191

[14] Mishra, R (2015), "Use of Power Looms in Kashmir Shawl Industry", International Journal of Textile and Fashion Technology (IJTFT), vol 5.(1) Pp 29-32

[15] Pargai, D and Shahnaz ,J(2016), " Revival of Handloom Industry: Need of the hour", International Journal of Textile and Fashion Technology (IJTFT), vol 6.(2) Pp 9-14

[16] Rudiger, D et.al (2004), Macroeconomics, nine and eleventh edition, New York McGrow Hill Irwin 
[17] Ravallion, M., and S. Chen (2005): "Hidden impact? Household saving in response to a poor-area development project," Journal of Public Economics, 89(11-12), 2183-2204

[18] Saikia, L (2019), "Mirroring the sociocultural ethos of Assamese life: A critical Reading with special reference to Assamese Marriage songs", International Journal of English and Literature (IJEL), Vol 9(4), Pp 19-24

[19] Singh P.V, and Punia P (2017)," Consumer Acceptability for Diversified Durrie Products", International Journal of Applied and Natural sciences (IJANS), vol 6(3) Pp 41-44

\section{Appendix}

Table 1Small saving (India) in Rs. billion
[20] Somasundaram, V (1999),"A Study on the Savings and Investment Pattern of Salaried Class in Coimbatore District", Ph.D Thesis submitted to Bharathiar University, Coimbatore.

[21] Yuh, Y and Hanna, S. D. (2010), "Which Households Think they Save?", Journal of Consumer Affairs, vol. 44(1), Pp70-97.

[22] Yao, R., Xian,J . J and Liao, L (2014) "Effect of Age On Saving Motives of Chinese Urban Consumers", Journal of Family and Economic issues, Human Development and Family studies Publication, The University of Rhode Island. Retrieved 22nd July 2017 on 3:50 P.M, from http://link.spinger.com/article

\begin{tabular}{|c|c|c|c|c|c|c|c|c|c|c|}
\hline \multirow[t]{3}{*}{ year } & \multicolumn{2}{|c|}{$\begin{array}{l}\text { Post } \quad \text { office } \\
\text { saving }\end{array}$} & \multicolumn{2}{|c|}{$\begin{array}{l}\text { National } \\
\text { saving } \\
\text { scheme1987 }\end{array}$} & \multicolumn{2}{|c|}{$\begin{array}{l}\text { National } \\
\text { saving } \\
\text { scheme1992 }\end{array}$} & \multicolumn{2}{|c|}{$\begin{array}{l}\text { Monthly income } \\
\text { scheme }\end{array}$} & \multicolumn{2}{|c|}{$\begin{array}{l}\text { Senior citizen } \\
\text { scheme }\end{array}$} \\
\hline & receipt & $\begin{array}{l}\text { outstan } \\
\text { ding }\end{array}$ & $\begin{array}{l}\text { receip } \\
\mathrm{t}\end{array}$ & $\begin{array}{l}\text { outsta } \\
\text { nding }\end{array}$ & $\begin{array}{l}\text { receip } \\
t\end{array}$ & $\begin{array}{l}\text { outsta } \\
\text { nding }\end{array}$ & receipt & $\begin{array}{l}\text { outstan } \\
\text { ding }\end{array}$ & $\begin{array}{l}\text { receip } \\
\mathrm{t}\end{array}$ & $\begin{array}{l}\text { outstandin } \\
\mathrm{g}\end{array}$ \\
\hline & 1 & 2 & 3 & 4 & 5 & 6 & 7 & 8 & 9 & 10 \\
\hline $1990-91$ & 42.53 & 42.05 & 20.85 & 45.92 & - & - & 8.73 & 23.40 & - & \\
\hline 2001-02 & 140.77 & 100.45 & 5.48 & 30.32 & .67 & 7.85 & 187.98 & 573.35 & - & \\
\hline $2002-03$ & 176.12 & 115.94 & 5.08 & 32.35 & 1.77 & 7.91 & 276.41 & 809.15 & - & \\
\hline $2003-04$ & 217.20 & 133.67 & 4.54 & 33.80 & .55 & 7.63 & 388.51 & $\begin{array}{l}1133.8 \\
6\end{array}$ & - & \\
\hline 2004-05 & 248.24 & 148.70 & 2.31 & 32.16 & .98 & 7.36 & 484.57 & $\begin{array}{l}1510.2 \\
6\end{array}$ & 84.74 & 54.36 \\
\hline $2005-06$ & 314.32 & 167.90 & 2.90 & 33.83 & .02 & 6.74 & 472.73 & $\begin{array}{l}1830.7 \\
7\end{array}$ & 74.36 & 159.16 \\
\hline 2006-07 & 360.67 & 185.65 & 3.64 & 42.02 & .34 & 6.55 & 264.61 & $\begin{array}{l}1894.4 \\
0\end{array}$ & 72.39 & 222.84 \\
\hline $2007-08$ & 431.65 & 197.89 & 2.75 & 40.30 & .46 & 6.09 & 170.25 & $\begin{array}{l}1823.9 \\
0\end{array}$ & 20.11 & 221.97 \\
\hline 2008-09 & 536.00 & 226.90 & 2.37 & 38.62 & .44 & 5.65 & 238.12 & $\begin{array}{l}1795.0 \\
4\end{array}$ & 13.83 & 206.51 \\
\hline $2009-10$ & 680.46 & 264.58 & 2.87 & 38.74 & .27 & 5.77 & 543.00 & $\begin{array}{l}2016.9 \\
4\end{array}$ & 96.26 & 249.89 \\
\hline $2010-11$ & 843.54 & 301.01 & 4.81 & 42.31 & .13 & 4.78 & 566.93 & $\begin{array}{l}2186.7 \\
4 \\
\end{array}$ & $\begin{array}{l}113.9 \\
5\end{array}$ & 309.13 \\
\hline $2011-12$ & 859.05 & 340.70 & 1.38 & 40.58 & 0.13 & 4.07 & 4.07 & $2,052.8$ & 29.86 & 267.63 \\
\hline
\end{tabular}




\begin{tabular}{|l|l|l|l|l|l|l|l|l|l|l|}
\hline & & & & & & & & 8 & & \\
\hline $2012-13$ & 839.00 & 378.50 & 1.41 & 39.63 & -0.01 & 3.26 & 190.49 & $\begin{array}{l}2,017.8 \\
7\end{array}$ & 19.78 & 240.93 \\
\hline $2013-14$ & 946.50 & 430.17 & 0.80 & 38.69 & .05 & 2.77 & 179.91 & $\begin{array}{l}2,020.8 \\
5\end{array}$ & 19.94 & 224.92 \\
\hline $2014-15$ & $\begin{array}{l}1,142 . \\
29\end{array}$ & 474.28 & 0.44 & 36.89 & 0.03 & 2.32 & 215.69 & $\begin{array}{l}2,005.5 \\
7\end{array}$ & 30.11 & 179.75 \\
\hline $2015-16$ & $\begin{array}{l}1,574 . \\
15\end{array}$ & 615.67 & 0.51 & 34.97 & 0.06 & 1.21 & 315.26 & $\begin{array}{l}1,938.0 \\
8\end{array}$ & $\begin{array}{l}103.2 \\
1\end{array}$ & 228.76 \\
\hline $2016-17$ & $\begin{array}{l}2,474 . \\
46\end{array}$ & 920.64 & 0.56 & 33.01 & 0.01 & -0.48 & 353.34 & $\begin{array}{l}1,800.6 \\
6\end{array}$ & $\begin{array}{l}100.0 \\
2\end{array}$ & 294.53 \\
\hline $2017-18$ & 171.45 & $\begin{array}{l}1,092.1 \\
0\end{array}$ & -1.62 & 31.38 & 0.05 & -0.43 & 16.25 & $\begin{array}{l}1,816.9 \\
1\end{array}$ & $\begin{array}{l}122.6 \\
4\end{array}$ & 417.18 \\
\hline
\end{tabular}

\begin{tabular}{|c|c|c|c|c|c|c|c|c|}
\hline \multirow[t]{3}{*}{ year } & \multicolumn{2}{|c|}{$\begin{array}{l}\text { Post Office Time } \\
\text { Deposits }\end{array}$} & \multicolumn{2}{|c|}{$\begin{array}{l}\text { Post Office } \\
\text { Recurring Deposits }\end{array}$} & \multicolumn{2}{|c|}{ Saving Certificates } & \multicolumn{2}{|c|}{$\begin{array}{l}\text { Public Provident } \\
\text { Fund }\end{array}$} \\
\hline & receipt & $\begin{array}{l}\text { outstan } \\
\text { ding }\end{array}$ & receipt & $\begin{array}{l}\text { outstandin } \\
\mathrm{g}\end{array}$ & receipt & $\begin{array}{l}\text { outstandin } \\
\mathrm{g}\end{array}$ & receipt & $\begin{array}{l}\text { outstandin } \\
\mathrm{g}\end{array}$ \\
\hline & 11 & 12 & 13 & 14 & 15 & 16 & 17 & 18 \\
\hline 1990-91 & 7.46 & 29.73 & 14.28 & 26.38 & 16.09 & 31.35 & - & - \\
\hline $2001-02$ & 64.45 & 102.61 & $\begin{array}{l}118.1 \\
1\end{array}$ & 236.48 & 78.40 & 402.05 & 19.29 & 81.11 \\
\hline $2002-03$ & 102.83 & 156.08 & $\begin{array}{l}139.9 \\
3\end{array}$ & 280.84 & 95.83 & 445.25 & 23.37 & 101.56 \\
\hline $2003-04$ & 163.39 & 240.67 & $\begin{array}{l}166.4 \\
5\end{array}$ & 339.63 & $\begin{array}{l}113.9 \\
7\end{array}$ & 445.25 & 25.28 & 122.67 \\
\hline 2004-05 & 202.53 & 319.94 & $\begin{array}{l}199.7 \\
9\end{array}$ & 411.02 & $\begin{array}{l}100.9 \\
7\end{array}$ & 551.28 & 25.34 & 142.73 \\
\hline $2005-06$ & 205.26 & 388.79 & $\begin{array}{l}234.8 \\
8\end{array}$ & 501.88 & $\begin{array}{l}105.4 \\
1\end{array}$ & 585.41 & 30.24 & 168.72 \\
\hline 2006-07 & 197.98 & 367.14 & $\begin{array}{l}263.3 \\
9\end{array}$ & 602.28 & 89.12 & 589.13 & 40.65 & 194.57 \\
\hline $2007-08$ & 140.42 & 299.41 & $\begin{array}{l}276.8 \\
4\end{array}$ & 650.71 & 62.85 & 573.88 & 33.47 & 213.58 \\
\hline 2008-09 & 132.53 & 262.65 & $\begin{array}{l}276.8 \\
4\end{array}$ & 650.72 & 70.82 & 553.09 & 36.52 & 234.02 \\
\hline $2009-10$ & 170.41 & 275.73 & $\begin{array}{l}303.5 \\
3\end{array}$ & 628.18 & $\begin{array}{l}105.1 \\
7\end{array}$ & 547.76 & 41.96 & 260.96 \\
\hline $2010-11$ & 162.17 & 284.45 & $\begin{array}{l}328.6 \\
2\end{array}$ & 612.50 & 97.57 & 546.42 & 68.37 & 315.83 \\
\hline $2011-12$ & 136.52 & 273.91 & $\begin{array}{l}344.9 \\
5\end{array}$ & 626.61 & $\begin{array}{l}179.7 \\
7\end{array}$ & $2,098.70$ & 62.22 & 359.93 \\
\hline $2012-13$ & 191.53 & 330.09 & $\begin{array}{l}358.9 \\
9\end{array}$ & 679.62 & $\begin{array}{l}191.2 \\
9\end{array}$ & $1,958.87$ & 72.21 & 411.21 \\
\hline
\end{tabular}




\begin{tabular}{|l|l|l|l|l|l|l|l|l|}
\hline 2013-14 & 246.74 & 407.14 & $\begin{array}{l}386.4 \\
6\end{array}$ & 741.49 & $\begin{array}{l}169.4 \\
6\end{array}$ & $1,882.58$ & 70.74 & 466.08 \\
\hline $2014-15$ & 330.69 & 517.57 & $\begin{array}{l}418.2 \\
4\end{array}$ & 745.13 & $\begin{array}{l}192.5 \\
2\end{array}$ & $1,834.10$ & 81.57 & 527.48 \\
\hline $2015-16$ & 424.53 & 706.35 & $\begin{array}{l}403.1 \\
5\end{array}$ & 761.79 & $\begin{array}{l}326.1 \\
0\end{array}$ & $1,942.42$ & 77.91 & 576.03 \\
\hline 2016-17 & 476.65 & 796.58 & $\begin{array}{l}474.5 \\
1\end{array}$ & 844.53 & $\begin{array}{l}289.8 \\
5\end{array}$ & $1,989.35$ & $\begin{array}{l}172.3 \\
5\end{array}$ & 633.61 \\
\hline 2017-18 & 196.33 & 992.92 & 78.68 & 923.20 & 79.43 & $2,066.76$ & 66.23 & 699.85 \\
\hline
\end{tabular}

Source: RBI Bulletin different series and Accountant General, Post and Telegraphs

Table 2 Augmented Dickey Fuller output for stationary

Post office saving, receipt, trend lags $(0)$

Dickey-Fuller test for unit root Number of obs $=16$

\begin{tabular}{|lcccc|}
\hline-- & & \\
\hline & Test statistics & $1 \%$ Critical value & $5 \%$ Critical value & 10\% Critical value \\
\hline \hline $\mathrm{Z}(\mathrm{t})$ & -4.685 & -4.380 & -3.600 & -3.240 \\
\hline \multicolumn{2}{|l|}{ MacKinnon approximate $\mathrm{p}$-value for $\mathrm{Z}(\mathrm{t})=0.0007$} \\
\hline
\end{tabular}

Monthly saving scheme, outstanding trend $\operatorname{lags}(0)$

Dickey-Fuller test for unit root Number of obs $=16$

- Interpolated Dickey-Fuller

Test Statistic $\quad 1 \%$ Critical Value $\quad 5 \%$ Critical Value $10 \%$ Critical Value

\begin{tabular}{lllll}
\hline $\mathrm{Z}(\mathrm{t})$ & -4.686 & -4.380 & -3.600 & -3.240
\end{tabular}

MacKinnon approximate $\mathrm{p}$-value for $\mathrm{Z}(\mathrm{t})=0.0007$

Provident fund, receipt, trend lags $(0)$

Dickey-Fuller test for unit root Number of obs $=16$

\begin{tabular}{|lccccc|}
\hline- & & \\
\hline & Test Statistic & $1 \%$ Critical Value & $5 \%$ Critical & Value & 10\% Critical Value \\
\hline \hline $\mathrm{Z}(\mathrm{t})$ & -6.241 & -4.380 & -3.600 & -3.240 \\
\hline
\end{tabular}

National saving scheme,1992, receipt, trend lags(0) 
Dickey-Fuller test for unit root Number of obs $=16$

Interpolated Dickey-Fuller

Test Statistic 1\% Critical Value 5\% Critical Value $10 \%$ Critical Value

\begin{tabular}{lllll}
\hline $\mathrm{Z}(\mathrm{t})$ & -4.721 & -4.380 & -3.600 & -3.240
\end{tabular}

MacKinnon approximate $\mathrm{p}$-value for $\mathrm{Z}(\mathrm{t})=0.0006$

Senior citizen scheme, outstanding $\operatorname{lags}(0)$

Dickey-Fuller test for unit root Number of obs $=13$

---------- Interpolated Dickey-Fuller

\begin{tabular}{|lcccc}
\hline & Test Statistic & $1 \%$ Critical Value & $5 \%$ Critical Value & $10 \%$ Critical Value \\
\hline $\mathrm{Z}(\mathrm{t})$ & -4.999 & -3.750 & -3.000 & -2.630 \\
\hline
\end{tabular}

National saving scheme 1987(outstanding) D1, lags(0)

Dickey-Fuller test for unit root Number of obs $=15$

Interpolated Dickey-Fuller

\begin{tabular}{|c|c|c|c|c|}
\hline & Test Statistic & $1 \%$ Critical Value & $5 \%$ Critical Value & $10 \%$ Critical Value \\
\hline $\mathrm{Z}(\mathrm{t})$ & -3.450 & -3.750 & -3.000 & -2.630 \\
\hline
\end{tabular}

Saving certificate (outstanding) D1, lags $(0)$

Dickey-Fuller test for unit root Number of obs $=15$

\begin{tabular}{|lcccc|}
\hline--------- & Interpolated Dickey-Fuller -------- & & \\
\hline & Test Statistic & $1 \%$ Critical Value & $5 \%$ Critical Value & $10 \%$ Critical Value \\
\hline $\mathrm{Z}(\mathrm{t})$ & -4.050 & -3.750 & -3.000 & -2.630 \\
\hline
\end{tabular}

MacKinnon approximate $\mathrm{p}$-value for $\mathrm{Z}(\mathrm{t})=0.0012$

Senior citizen scheme (receipt)D1, $\operatorname{lags}(0)$

Dickey-Fuller test for unit root Number of obs $=12$

\begin{tabular}{|lcccc|}
\hline \hline & Test Statistic & $1 \%$ Critical Value & $5 \%$ Critical Value & $10 \%$ Critical Value \\
\hline $\mathrm{Z}(\mathrm{t})$ & -2.851 & -3.750 & -3.000 & -2.630 \\
\hline
\end{tabular}


MacKinnon approximate $\mathrm{p}$-value for $\mathrm{Z}(\mathrm{t})=0.0514$

Post office recurring deposit (outstanding)D1, $\operatorname{lags}(0)$

Dickey-Fuller test for unit root Number of obs $=15$

Interpolated Dickey-Fuller

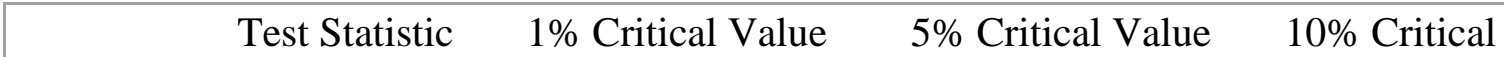

Value

$\mathrm{Z}(\mathrm{t}) \quad-2.723 \quad-3.750 \quad-3.000 \quad-2.630$

MacKinnon approximate $\mathrm{p}$-value for $\mathrm{Z}(\mathrm{t})=0.0702$

Provident fund (outstanding)D1, lags(0)

Dickey-Fuller test for unit root Number of obs $=15$

--------- Interpolated Dickey-Fuller

\begin{tabular}{|c|c|c|c|c|}
\hline Value & Test Statistic & $1 \%$ Critical Value & $5 \%$ Critical Value & $10 \%$ Critical \\
\hline $\mathrm{Z}(\mathrm{t})$ & -2.990 & -3.750 & -3.000 & -2.630 \\
\hline
\end{tabular}

Post office saving (outstanding) D2, lags(0)

Dickey-Fuller test for unit root Number of obs $=14$

Interpolated Dickey-Fuller

Test Statistic $1 \%$ Critical Value $5 \%$ Critical Value

$10 \%$ Critical

Value

\begin{tabular}{llllr}
\hline $\mathrm{Z}(\mathrm{t})$ & -3.716 & -3.750 & -3.000 & -2.630
\end{tabular}

MacKinnon approximate $\mathrm{p}$-value for $\mathrm{Z}(\mathrm{t})=0.0039$

Monthly saving scheme (receipt) D2, lags(0)

Dickey-Fuller test for unit root Number of obs $=14$

\begin{tabular}{|lcccc|}
\hline- -------- Interpolated Dickey-Fuller & -------- \\
\hline & Test Statistic & 1\% Critical Value & 5\% Critical Value & 10\% Critical \\
\hline $\mathrm{Z}(\mathrm{t})$ & -2.872 & -3.750 & -3.000 & -2.630 \\
\hline
\end{tabular}


Saving certificate (receipt)D2, lag (0)

Dickey-Fuller test for unit root Number of obs $=14$

\begin{tabular}{|c|c|c|c|c|}
\hline \multicolumn{5}{|c|}{---------- Interpolated Dickey-Fuller --------- } \\
\hline & Test Statistic & $1 \%$ Critical Value & $5 \%$ Critical Value & $10 \%$ Value Critical \\
\hline $\mathrm{Z}(\mathrm{t})$ & -2.872 & -3.750 & -3.000 & -2.630 \\
\hline
\end{tabular}

MacKinnon approximate $\mathrm{p}$-value for $\mathrm{Z}(\mathrm{t})=0.0488$

Post office time deposit (receipt) D2, lag (0)

Dickey-Fuller test for unit root Number of obs $=14$

Interpolated Dickey-Fuller

\begin{tabular}{|lcccc|}
\hline & Test Statistic & $1 \%$ Critical Value & $5 \%$ Critical Value & 10\% Critical Value \\
\hline \hline $\mathrm{Z}(\mathrm{t})$ & -2.872 & -3.750 & -3.000 & -2.630 \\
\hline
\end{tabular}

Post office time deposit (outstanding)D2, lags(0)

Dickey-Fuller test for unit root Number of obs $=14$

\begin{tabular}{|c|c|c|c|c|}
\hline \multicolumn{5}{|c|}{--------- Interpolated Dickey-Fuller -------- } \\
\hline & Test Statistic & $1 \%$ Critical Value & $5 \%$ Critical Value & $10 \%$ Value Critical \\
\hline $\mathrm{Z}(\mathrm{t})$ & -7.333 & -3.750 & -3.000 & -2.630 \\
\hline
\end{tabular}

MacKinnon approximate $\mathrm{p}$-value for $\mathrm{Z}(\mathrm{t})=0.0000$

Post office recurring deposit (receipt), D2 lags(0)

Dickey-Fuller test for unit root Number of obs $=14$

--------- Interpolated Dickey-Fuller

\begin{tabular}{|llll}
\hline Test Statistic $\quad 1 \%$ Critical Value $\quad 5 \%$ Critical $\quad 10 \%$ Critical &
\end{tabular}

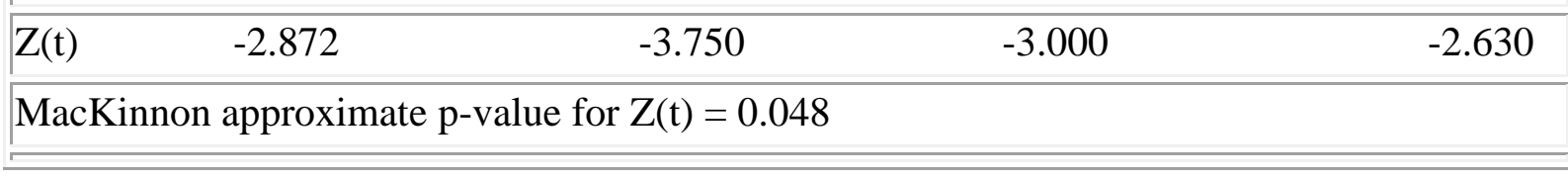

Note: D1 represent first differenced

D2 represent second differenced 